\title{
Multicultural Classroom Management: Strategies for Managing the Diversity of Students in Elementary Schools and Madrasah Ibtidaiyah
}

\section{Pengelolaan Kelas Multikultural: Strategi Mengelola Keberagaman Peserta Didik di Sekolah Dasar dan Madrasah Ibtidaiyah}

\author{
Fita Mustafida \\ Universitas Islam Malang \\ fita.mustafida@unisma.ac.id
}

DOI: $10.18860 /$ mad.v13i2.11061

Abstract. A comfortable classroom environment cannot be separated from the role of the teacher in managing the learning environment. Heterogeneous classroom conditions are a challenge for teachers to create a conducive and meaningful learning atmosphere. This is because each student has different characters, needs, and potentials that need to be developed. On the other hand, the heterogeneity of students if not managed properly can be a source of various problems in the classroom. Starting from bullying, the learning atmosphere is uncontrollable, even the attitude of antipathy to the diversity triggers other negative attitudes, such as discrimination and injustice. Therefore, to overcome this problem, it requires the ability of teachers to create a classroom environment that respects diversity (multicultural). Based on this view, multicultural class management is needed. This is because multicultural classroom management is believed to be able to foster student diversity while still adhering to universal human values that are just and in favor of equality. Multicultural classroom management is also able to provide educational services that are by human needs, and respect differences with the human approach. On this basis, this study discusses teacher strategies in managing the diversity of students using a multicultural classroom management approach. Multicultural classroom management needs to be developed to create a more humanist and democratic learning atmosphere which is needed to foster the diversity of students in the classroom. Among the multicultural class management strategies that can be carried out are managing gender diversity, social status, ethnicity, including intelligence.

Keywords. Classroom Management; Multicultural; Student Diversity

Abstrak. Lingkungan kelas yang nyaman tidak lepas dari peran guru dalam mengelola lingkungan pembelajaran. Kondisi kelas yang heterogen menjadi tantangan bagi guru untuk menciptakan suasana pembelajaran yang kondusif dan bermakna. Hal ini dikarenakan setiap siswa memiliki perbedaan karakter, kebutuhan, serta potensinya masing-masing yang perlu dikembangkan. Di sisi lain, heterogenitas peserta didik jika tidak dikelola dengan baik dapat menjadi sumber munculnya berbagai problem di kelas. Mulai dari bullying, suasana pembelajaran tidak terkendali, bahkan sikap antipati terhadap keberagaman yang memicu sikap negatif lain, seperti diskriminasi dan ketidakadilan. Oleh karenanya, untuk mengatasi problem tersebut, diperlukan kemampuan guru menciptakan lingkungan kelas yang menghargai keragaman (multikultural). Berdasarkan pandangan tersebut, maka pengelolaan kelas multikultural sangat diperlukan. Hal ini dikarenakan, pengelolaan kelas multikultural 
diyakini mampu membina keragaman siswa dengan tetap berprinsip pada nilai-nilai universal kemanusiaan yang berkeadilan dan memihak pada aspek kesederajatan. Pengelolaan kelas multikultural juga mampu memberi pelayanan pendidikan yang sesuai dengan kebutuhan manusia, serta menghargai perbedaan dengan pendekatan manusia (human approach). Atas dasar tersebut, maka kajian ini membahas tentang strategi guru dalam mengelola keragaman peserta didik dengan menggunakan pendekatan pengelolaan kelas yang multikultural. Pengelolaan kelas multikultural perlu dikembangkan guna menciptakan suasana pembelajaran yang lebih humanis dan demokratis yang sangat dibutuhkan untuk membina keberagaman siswa di kelas. Diantara strategi pengelolaan kelas multikultural yang dapat dilakukan adalah mengelola keragaman gender, status sosial, etnis, termasuk kecerdasan.

Kata kunci; Pengelolaan Kelas, Multikultural, Keberagaman Peserta Didik

Received: $21-12-2020$

Revised: 12-01-2021
Approved: 14-01-2021

Published: 29-03-2021

Copyright (C) Madrasah Jurnal Pendidikan dan Pembelajaran Dasar. All Right Reserved. This is an open access article under the CC BY-SA license (Creative Commons Attribution-ShareAlike 4.0 International License.).

Correspondence Address: fita.mustafida@unisma.ac.id

\section{A. PENDAHULUAN}

Pengelolaan kelas merupakan kegiatan paling menantang bagi guru. Penelitian Arends (2008) mengungkapkan bahwa tantangan paling sulit yang dihadapi guru dalam menciptakan lingkungan belajar yang optimal adalah mengelola lingkungan kelas. Pandangan tersebut diperkuat oleh Oliver et al. (2011) yang menegaskan adanya temuan banyaknya keluhan guru dikarenakan sulitnya dalam mengelola kelas. Menurut Nugraha (2018), pengelolaan kelas yang baik berdampak pada efektifitas mencapai tujuan pembelajaran. Sebaliknya, kelas yang tidak dapat dikelola dengan baik menjadi sumber munculnya berbagai masalah yang dapat menghambat kelancaran kegiatan pembelajaran.

Di sisi lain, perjumpaan berbagai keragaman dan budaya di ruang kelas (classroom) tidak bisa dihindari. Setiap peserta didik memiliki karakter, kebutuhan serta latar belakang yang berbeda. Jika keragaman tersebut tidak dapat dikelola dengan baik, maka dapat mendorong munculnya kesenjangan/konflik yang dapat menghambat keberhasilan pembelajaran. Perasaan egoisme, keangkuhan dan sikap eksklusif juga berpotensi tumbuh dan berkembang subur akibat fenomena ini (Chandra, 2015). Oleh karenanya, untuk mengakomodir keragaman-keragaman yang ada, guru dapat melakukannya dengan membangun suasana akademik yang menghargai keragaman kultural.

Pernyataan di atas, selaras dengan hasil penelitian Tomlinson \& Imbeau (2010) bahwa terdapat banyak kerumitan yang dihadapi guru dalam mengelola siswa di kelas yang diakibatkan minimnya guru yang mengajar dengan memperhatikan keragaman atau karakter individual siswanya. Kepiawaian guru dalam mengelola keragaman siswa juga dipercaya dapat memberi dampak terhadap kenyamanan dan kondisi sosio 
emosional yang terbangun antara guru-siswa di dalam kelas (Mustafida, Fita, Abd, Gafur, 2019).

Masuknya ideologi multikulturalisme dalam pendidikan sejalan dengan kebutuhan ini. Sehingga implementasi pendidikan multikultural yang berprinsip pada "pengakuan keberagaman di atas kesederajatan" dapat memberi pelayanan pendidikan yang sesuai dengan kebutuhan manusia, serta menghargai perbedaan dengan pendekatan manusia (human approach). Sleeter (2001) merekomendasikan upaya preventif pengelolaan keragaman siswa di kelas melalui upaya peng-akomodiran keberagaman siswa yang menghargai keragaman dan responsif terhadap budaya. Salah satu yang dapat dilakukan guru dalam mengelola keragaman tersebut adalah melalui pengelolaan kelas, sebagaimana Kadir (2014) menjelaskan bahwa di antara aspek yang menjadi fokus pengelolaan kelas adalah bagaimana mengelola keragaman latar belakang siswa dan kemampuan belajarnya. Hal ini juga relevan dengan penelitian Sturz et al. (2005) yang menyatakan bahwa diantara tehnik yang dapat diterapkan dalam pembelajaran untuk mengakomodasi siswa dari berbagai latar belakang keragaman lebih difokuskan pada pengelolaan lingkungan kelas. Oleh karenanya, untuk menjawab permasalahan di atas maka inovasi guru dalam mengelola keragaman peserta didik perlu dilakukan melalui pengelolaan kelas yang didasarkan pada nilainilai multikultural. Melalui pengelolaan kelas multicultural diharapkan menjadi alternatif strategi pengelolaan kelas yang humanis dan terbuka terhadap keragaman.

Bertolak pada uraian di atas, maka penting bagi guru memiliki kemampuan menciptakan lingkungan kelas yang multikultural, kakni dengan menerapkan strategi pengelolaan lingkungan pembelajaran yang menghargai keragaman kultural peserta didik. Dengan pengelolaan kelas yang menghargai keragaman kultural, diharapkan mampu mengembangkan keterampilan-keterampilan untuk mengembangkan diri, bekerjasama dengan orang lain yang mendukung terhadap keragaman dan keadilan sosial (Mustafida, Fita, Abd, 2019).

Berdasarkan alasan tersebut, maka kajian ini penting dilakukan untuk memberikan wawasan baru, serta pemahaman tentang gambaran riil penerapan strategi pengelolaan kelas yang menghargai keragaman peserta didik di ruang kelas.

\section{B. METODE PENELITIAN}

Artikel ini merupakan kajian penelitian kepustakaan (library research) menggunakan metode literature review. Literature review merupakan jenis penelitian kepustakaan yang dilakukan dengan membaca berbagai buku, jurnal, dan terbitanterbitan lain yang berkaitan dengan topik penelitian, untuk menghasilkan satu tulisan yang berkenaan dengan isu tertentu (Jill Jesson, Lydia Matheson, 2011).

Pada kajian ini, penulis mengkaji dokumen-dokumen primer dari jurnal dan buku-buku berkualitas yang relevan dengan topik penelitian yang dikaji. Analisis data menggunakan metode deskriptif supaya hasilnya dapat dijabarkan secara mendalam, terperinci, dan detail. Langkah analisis diawali dengan penentuan topik penelitian yang dilanjutkan dengan meninjau literatur, reduksi literatur untuk menemukan bukti dan temuan, pengorganisasian literatur, review literatur dan pengambilan kesimpulan (Lawrence A. Machi, 2016). Adapun tema-tema fokus kajian penelitian ini di antaranya: keragaman dan karakter peserta didik, pengelolaan kelas, masalah-masalah pengelolaan kelas, pendidikan multikultural beserta prinsip dan nilai-nilainya sebagai

Vol. 13 No. 2 Juni 2021

Madrasah homepage: http://ejournal.uin-malang.ac.id/index.php/madrasah/index 


\section{MADRASAH}

Jurnal Pendidikan dan Pembelajaran Dasar

p ISSN: 1979-5599 | e ISSN: 2502-194X

basis dalam menemukan strategi pengelolaan kelas yang yang lebih menghargai keberagaman.

\section{PEMBAHASAN}

\section{Memahami Pengelolaan kelas}

Pengelolaan kelas merupakan bagian dari kegiatan guru dalam mengelola pembelajaran di kelas. Pengelolaan kelas dianggap penting karena perannya dalam mengorganisir dan mengkondisikan siswa selama kegiatan pembelajaran berlangsung. Sepintar apapun guru, atau sehebat apapun guru dalam menyampaikan materi pembelajaran, jika kondisi kelas tidak dapat diorganisir dengan baik, maka guru juga akan kesulitan memberikan pengalaman belajar yang bermakna kepada siswa.

Terkait makna kelas. Imron (2003) mengartikan kelas sebagai ruang atau tempat siswa belajar. Ruangan ini diidentikkan dengan sebuah tempat yang dibatasi empat dinding, dan ada tingkatan (grade). Pandangan ini selaras dengan pendapat Nawawi yang memandang kelas dari sudut pandang sempit sebagai ruangan yang dibatasi oleh empat dinding, dan tempat berkumpulnya siswa untuk mengikuti pembelajaran (Nawawi, 1982). Meskipun dari sudut pandang lain, ia juga memandang kelas sebagai masyarakat kecil bagian dari masyarakat sekolah. Sementara itu, jika dilihat dari sudut pandang manajemen, pengelolaan kelas dapat dimaknai sebagai upaya untuk mengatur kelas dengan seperangkat perencanaan, serta implementasi pengelolaan ruang-ruang kelas, dan kontrol kelas (Erwinsyah, 2017).

Dalam literatur lain, Mustafida (2016), berpendapat bahwa pengelolaan kelas merupakan upaya guru yang berkaitan dengan aspek pengelolaan fisik (ruang kelas) dan pembinaan prilaku siswa di kelas. Oleh karena itu, pengelolaan kelas tidak sekedar mengenai aspek-aspek pengelolaan ruang kelas, tetapi juga bagaimana mengelola siswa di kelas supaya dapat melaksanakan kegiatan pembelajaran dengan baik. Hal ini juga diperkuat dengan pendapat Arikunto (1992) yang membagi sasaran pengelolaan kelas meliputi dua, yaitu: pengaturan fisik (ruang kelas, perabot, dan tugas-tugas) dan juga pengaturan siswa (prilaku dan kegiatan belajar siswa di kelas) agar kondisi kelas tetap optimal untuk belajar. Atas dasar itulah Djigic \& Stojiljkovic (2011) memaknai pengelolaan kelas sebagai semua tindakan guru yang bertujuan untuk membangun lingkungan belajar yang stimulatif dan komprehensif.

Berdasarkan sasaran tersebut, mempertegas bahwa guru sebagai pengelola kelas tidak sekedar menyiapkan materi pembelajaran, menyampaikan pembelajaran, dan mengevaluasi perkembangan hasil belajar siswa saja, tetapi juga berkaitan dengan tugas membina dan menciptakan, memelihara serta memperbaiki sistem atau organisasi kelas, sehingga peserta didik betah dan nyaman di dalam kelas sehingga dapat membangun motivasi untuk selalu belajar. Disinilah peran guru sebagai pengelolaan kelas menjadi penting untuk mendayagunakan dan mengembangkan potensi peserta didik. Pengelolaan kelas yang efektif mengharuskan guru menerapkan pelajaran yang dinamis, memperkuat perilaku positif, dan mengintervensi perilaku buruk sejak dini dan efisien (Gregory \& Jones, 2013). Melalui pengelolaan kelas yang baik, diharapkan dapat menunjang keberhasilan proses interaksi belajar mengajar. Hal ini selaras dengan pandangan Mustafida dan Gafur (2019) yang mengemukakan tujuan

Vol. 13 No. 2 Juni 2021

Madrasah homepage: http://ejournal.uin-malang.ac.id/index.php/madrasah/index 
pengelolaan kelas untuk memelihara dan membina kondisi kelas baik yang bersifat fisik-materi maupun perilaku siswa.

Pengelolaan kelas sangatlah penting bagi guru, sebab dengan pengelolaan yang baik siswa dapat belajar dengan baik dengan tetap memperhatikan pada kepuasan dan kebutuhan peserta didik dari berbagai aspek kebutuhan dan perkembangannya. Baik intelektual, moral, sosial maupun karakter sifat-sifat individualnya. Sebagaimana hasil penelitian Djigic \& Stojiljkovic (2011) yang juga menunjukkan adanya hubungan antara gaya pengelolaan kelas guru, dengan iklim kelas dan prestasi sekolah siswa.

\section{Menciptakan Lingkungan Kelas Multikultural}

Keadaan siswa di dalam sebuah kelas pastilah beragam. Setiap anak menyimpan berbagai potensi dan terus berkembang. Anak juga memiliki karakter dan kebutuhan yang berbeda-beda (Suteja, 2017). Hal ini dikarenakan setiap individu adalah makhluk sosial yang memiliki kebutuhan untuk dimiliki, diakui, dan diterima (Wiseman \& Hunt, 2008). Di lingkungan keluarga, anak mendapatkan perlakuan, pengasuhan dan pendidikan yang berbeda. Perbedaan latar belakang pengalaman tersebut seringkali berpengaruh terhadap pembentukan sikap dan pola pikir anak (Syarifah, 2017). Sebagaimana para empirisme meyakini bahwa pengalaman merupakan sumber pengetahuan (Dale H, 2012).

Perbedaan siswa tersebut antara lain keragaman suku, gender, agama dan kemampuan daya tangkap dalam memproses informasi yang disampaikan guru dalam pembelajaran. Selain aspek kemampuan daya serap. Di kelas juga terdapat keragaman siswa dari aspek yang lain mengingat siswa sebagai individu yang kompleks. Mulai dari potensi, karakteristik, kepribadian, identitas, talenta, bahkan kesadarannya untuk belajar (Aziz, Hamka Abdul, 2012). Dari keragaman tersebut, seyogyanya guru mampu mengelola dengan baik supaya interaksi positif dan individu yang beragam dapat terjadi. Sehingga siswa yang heterogen tersebut dapat bekerjasama dengan baik di kelas, saling menerima perbedaan satu sama lain yang dapat memunculkan tumbuhnya nilai toleransi yang tinggi antar peserta didik.

Sementara kelas yang multikultural merupakan kelas yang dihuni oleh berbagai macam karakter dan latar belang siswa yang berbeda namun mencerminkan adanya penerimaan dan penghargaan terhadap keragaman tersebut (Nadda, 2017). Lingkungan kelas yang multikultural ditandai dengan adanya rasa saling menghormati dan menghargai satu sama lain tanpa memandang latar belakang dan identitas yang melekat dalam peserta didik (Hardy \& Woodcock, 2015). Oleh karena itu, dalam menciptakan lingkungan pembelajaran yang multikultural (menghargai dan ramah perbedaan) di dalam kelas, diperlukan usaha yang intensif dari guru. Khususnya guru kelas untuk menata dan mengelola lingkungan belajar sehingga suasana kelas menjadi menyenangkan bagi semua siswa dengan latar belakang yang berbeda, namun tetap dalam suasana yang penuh keterbukaan, toleran dan kekeluargaan (Mustafida, Fita, $\mathrm{Abd}$, 2019). Oleh sebab itu, sebelum bertindak sebagai pengelola kelas yang multikultural guru harus membekali dirinya dengan pemahaman terhadap konsepkonsep pengelolaan kelas yang menghargai keragaman.

Pemahaman yang dimaksudkan adalah kemampuan guru dalam mempelajari dan mendalami teori-teori kegiatan mengelola kelas yang yang ramah karagaman serta inklusif atau terbuka. Salah satunya dengan menerapkan prinsip-prinsip kesadaran terhadap pentingnya menerapkan prosedur pengelolaan kelas yang adil dan

Vol. 13 No. 2 Juni 2021

Madrasah homepage: http://ejournal.uin-malang.ac.id/index.php/madrasah/index 


\section{MADRASAH}

Jurnal Pendidikan dan Pembelajaran Dasar

p ISSN: 1979-5599 | e ISSN: 2502-194X

berkesetaraan (Parker, 2016). Tentunya juga berprinsip pada nilai-nilai humanis, pluralis, dan demokratis untuk menciptakan atmosfir pembelajaran yang multikultural (Van Tartwijk et al., 2009). James S. Cangelosi (2013) juga menegaskan bahwa efektivitas strategi pengelolaan kelas dalam kegiatan belajar tergantung pada bagaimana anda berhubungan dengan siswa sebagai individu dan pemahaman anda terhadap latar belakang peserta didik. Keterampilan interpersonal guru menjadi kunci dalam membina berbagai keragaman di kelas sebagaimana teori pengelolaan keragaman siswa oleh Dreikurs (Wiseman \& Hunt, 2008).

Secara umum, lingkungan kelas multikultural terdiri dari lingkungan fisik dan psikis-sosial. Lingkungan fisik yang multikultural terjadi apabila di dalam kelas (ruang kelas) menggambarkan sebuah lingkungan yang menghargai keragaman. Seperti adanya penataan perabot dan tempat duduk siswa yang menghargai keragaman siswa dari aspek gender, umur, tingkat intelegensi, keragaman suku, ras bahkan agama (Mustafida \& Gafur, 2019). Bukan sebaliknya, fisik kelas didesain mengedepankan pada kebutuhan salah satu gender, umur, maupun kegemaran siswa. Sementara aspek psikis digambarkan melalui kenyamanan siswa di kelas. Kenyamanan berkaitan dengan bagaimana siswa dapat menerima keberagaman yang ada, siswa merasa enjoy, dan diterima dengan baik di kelas dengan suasana yang demokratis (Shepherd \& Linn, 2017).

Berdasarkan jabaran di atas, dapat dimaknai bahwa lingkungan psikis-sosial berkaitan dengan bagaimana suasana yang terbangun di kelas ditandai dengan adanya adanya rasa saling menghormati dan menghargai satu sama lain tanpa memandang latar belakang dan identitas yang melekat dalam peserta didik. Suasana inilah yang diharapkan mampu membangun situasi belajar yang kondisif karena adanya sikap menghargai keragaman baik dari aspek gender, umur, tingkat intelegensi, keragaman suku, ras bahkan agama.

\section{Mengembangkan Stategi Pengelolaan Kelas Multikultural}

Suasana belajar erat laitannya dengan iklim lingkungan tempat belajar dilakukan. Lingkungan ini dapat dimaknai sebagai segala sesuatu yang yang dapat dimanfaatkan untuk menunjang kegiatan pembelajaran. Lingkungan yang terbentuk dengan budaya yang tidak menghargai keragaman, biasanya sering memicu perasaan kurang bersahabat, diskriminatif, dan prasangka negatif (stereotype) ke arah budaya berbeda di sekitanya. Melalui pengelolaan kelas yang multikultural diharapkan berbagai prasangka negatif antar teman, sikap diskriminasi dan sikap "memandang rendah" orang lain yang memiliki budaya yang berbeda. Sebagai contoh kepercayaan bahwa kebudayaannya merupakan hal yang natural dan benar, sementara budaya orang lain adalah sesuatu yang aneh, serta cenderung menganggap budayanya paling baik yang menimbulkan rasa bangga berlebihan terhadap kebudayaannya sendiri (Barliana, M. Syaom, 2008).

Bertolak pada fenomena tersebut, maka pemahaman terhadap budaya antar individu maupun kelompok di kelas sangat diperlukan. Sebagaimana James S. Cangelosi (2013) yang menyatakan bahwa pemahaman guru tentang keanekaragaman budaya akan memberikan peluang positif bagi guru dalam membina dan memotivasi siswa untuk ikut terlibat dalam kegiatan pembelajaran di kelas secara massif yang selanjutnya ia katakan di sinilah pentingnya strategi pengelolaan kelas yang

Vol. 13 No. 2 Juni 2021

Madrasah homepage: http://ejournal.uin-malang.ac.id/index.php/madrasah/index 
multikultural digunakan sebagai cara atau tindakan yang dilakukan guru dalam mengelola lingkungan kelas yang menghargai keragaman (James S. Cangelosi, 2013).

Aspek penting lainnya yang tak kalah dari strategi di atas dalam mengelola keragaman di kelas adalah dengan membangun hubungan inklusif serta berkomunikasi yang baik. Cara guru berbicara dan berkomunikasi dengan siswa sangat mempengaruhi perilaku dan interaksi siswa di dalam kelas. Komunikasi yang baik menghasilkan iklim kondusif untuk pembelajaran berkualitas karena siswa mau bekerja sama dan menunjukkan disiplin positif (Hue \& Li, 2008). Strategi ini perlu dilakukan guru guna menciptakan lingkungan belajar yang saling memahami, saling menerima, dan menghargai perbedaan baik individu maupun kelompok di dalam kelas. Berikut contoh implementasi pengelolaan kelas multicultural dalam mengelola keragaman peserta didik di SD/MI.

\section{a. Mengelola Keragaman Gender di Kelas}

Pada umumnya di setiap kelas terdiri dari gender yang berbeda, yakni laki-laki dan perempuan. Adanya perbedaan jenis kelamin itulah menyebabkan perbedaan kecenderungan, perkembangan, dan kebutuhan yang berbeda antara anak laki-laki dan anak perempuan. Dalam pendidikan inklusi gender, perempuan dan laki-laki sama dalam mendapatkan hak pendidikan dan tidak bisa dibeda-dedakan (Junaidi, 2017). Untuk mengelola keberagaman gender di kelas, guru dapat melakukan dengan memahami kecenderungan-kecenderungan dari kedua gender yang berbeda, untuk dijadikan sebagai dasar mengelola kelas yang berprinsip pada kesetaraan gender sehingga anak-anak dengan perbedaan jenis kelamin tersebut dapat terwadahi oleh guru tidak ada yang diasingkan atau diperlakukan tidak adil. Adapun strategi yang dapat digunakan antara lain dengan penyelenggaraan pendidikan yang demokratis dan berkeadilan serta tidak diskriminatif. Melalui sosialisasi gender di dalam kelas dapat memastikan bahwa siswa perempuan dibuat sadar akan keberadaannya yang setara dengan laki-laki, sebaliknya siswa laki-laki sadar bahwa mereka memillki derajad yang setara dengan perempuan di muka publik. Sebagaimana Yaqin (2005) bahwa prinsip kesetaraan gender merupakan strategi dasar dalam membangun sikap sensitif gender di sekolah.

Contoh pengelolaan kelas berdasarkan gender dapat dilakukan guru melalui dua jenis pengelolaan. Pertama, melalui pengelolaan fisik; dengan mengelola ruang kelas beserta atribut di dalamnya yang ramah gender, tidak menggambarkan kecenderungan pada salah satu jenis gender. Pengelolaan gender dalam kelas juga dapat dilakukan melalui penghargaan terhadap karya siswa tanpa memandang jenis kelamin, yakni semua berkesempatan untuk memajang karya terbaik (Mustafida \& Gafur, 2019). Untuk membina prilaku sensitif gender pada anak dapat dilakukan dengan menanamkan nilai-nilai persamaan hak dan anti diskriminasi dengan cara memberikan contoh sikap adil dan tidak diskriminasi terhadap gender tertentu, serta meningkatkan sikap sensitif terhadap permasalahan gender (Yaqin, 2005).

\section{b. Mengelola Keragaman Status Sosial di Kelas}

Status sosial pada umumnya didasarkan pada tiga kategori yakni pekerjaan, ideologi dan keturunan. Untuk menyikapi hal tersebut, maka strategi pengelolaan kelas yang dapat dilakukan guru adalah dengan memberikan penyadaran dan menumbuhkan kesadaran kritis terhadap terhadap fenomena kesetaraan (egalit) serta menumbuhkan sikap peduli sosial tanpa melihat latar belakang status sosial anak

Vol. 13 No. 2 Juni 2021

Madrasah homepage: http://ejournal.uin-malang.ac.id/index.php/madrasah/index 


\section{MADRASAH}

Jurnal Pendidikan dan Pembelajaran Dasar

p ISSN: 1979-5599 | e ISSN: 2502-194X

(Kang et al., 2019). Seperti menempatkan posisi tempat duduk siswa yang heterogen dari status dan kelas sosial anak. Membagi kelompok belajar atau diskusi kelas dengan keragaman status sosial anak. Hal ini dilakukan untuk menghindari munculnya kelompok-kelompok atau geng "dengan predikat tertentu" yang didasarkan pada prestis seperti gengsi, maupun martabat dan wibawa di dalam masyarakat (Ritzer, 1991). Selain melalui pengelolaan tempat duduk guru juga harus tetap memberikan penyadaran kepada peserta didik tentang keragaman. Penyadaran dapat dilakukan melalui penanaman nilai-nilai keberagaman dengan menerapkan kegiatan pembelajaran dan pengelolaan kelas yang menghargai keragaman kultural. Sehingga melalui nilai-nilai keberagaman yang diperoleh siswa dapat hidup dengan sikap toleransi yang tinggi terhadap berbagai bentuk keragaman status sosial dari teman dan masyarakat di lingkungannya.

\section{c. Mengelola Keragaman Etnis di Kelas}

Keragaman etnis di kelas jika tidak dikelola dengan baik maka dapat menyebabkan munculnya prasangka-prasangka negatif seperti stereotip dan diskriminatif. Jika dibiarkan, pandangan ini dapat merusak hubungan baik pribadi maupun kelompok. Karena dengan stereotip dapat menjadikan seseorang sulit untuk berkembang ke arah kemajuan atas perkembangan budaya di luar dirinya, seakan menjadikan seseorang terkungkung pada budayanya sendiri, dan cenderung menolak perubahan yang ditimbulkan atas pengaruh budaya lain. Hal ini dikemukakan Banks yang dikutip oleh Tilaar dalam studi identitas etnik tentang tipologi sikap seseorang terhadap cultural ethnic yang ia sebut sebagai ethnic psychological captivity (Tilaar, 2003). Oleh karena itu, perlunya interaksi multikultural dibangun di kelas, guna menjalin hubungan sosial untuk saling mengenal satu sama lain dan dapat memunculkan rasa kasih sayang. Interaksi dapat menimbulkan saling percaya, tidak ada proses hegemoni dari kultur dominan atas kultur minoritas (Zamroni, 2011).

Implementasi pengelolaan kelas multi etnis dapat dilakukan melalui strategistrategi yang mempertimbangkan kepentingan seluruh peserta didik di kelas. Aplikasi strategi pengelolaan kelas berdasarkan etnis dapat dilakukan melalui pengembangan budaya egaliter (Smith, 2012). Budaya egaliter yang dimaksud adalah budaya kesejajaran agar rasa sombong atau merasa lebih tinggi dari etnis lain yang dapat memicu konflik dapat dihindari. Oleh karena itu aktivitas-aktivitas yang berbau kebersamaan perlu dibangun di kelas. Sehingga suasana saling menghargai, saling percaya dan dapat dipercaya, saling memegang etika, saling mendidik dan membina (Surata \& Andrianto, 2001).

Di antara contoh strategi yang dapat dikembangkan guru dalam mengelola keragaman etnis adalah membuat kelompok belajar lintas etnis. Maksudnya, dalam membagi kelompok di kelas sedapat mungkin terdiri dari siswa dengan etnis berbeda seperti anak etnis Arab digabungkan dengan anak dari etnis Jawa, Madura dan lainnya. Strategi ini perlu dilakukan untuk mengupayakan membawa siswa agar mengalami langsung interaksi dalam keragaman etnis. Semisal dengan membagi kelompok belajar, kelompok piket kelas yang terdiri dari siswa beragam etnis. Modifikasi keragaman kelompok ini juga dapat dilakukan dengan mengakomodir sekaligus keragaman baik etnik gender dan kebudayaan. Selain itu dalam mengelola kelas yang menghargai etnis dan atribut budayanya dapat dilakukan dengan interaksi interkultural (yakni melalui

Vol. 13 No. 2 Juni 2021

Madrasah homepage: http://ejournal.uin-malang.ac.id/index.php/madrasah/index 
komunikasi antar budaya). Cara ini diakui dapat memengaruhi proses komunikasi kita pada tingkat kesadaran atau ketidaktahun atas kelompok budaya (norma dan budaya) (Mustafida \& Gafur, 2019).

\section{d. Mengelola Keragaman Kecerdasan Siswa di Kelas}

Perbedaan kemampuan dan kecenderungan yang dimiliki siswa berkaitan erat dengan sikap dan prilaku siswa di kelas dalam belajar. Keberagaman ini diakibatkan faktor pengalaman siswa, seperi stimulasi perkembangan maupun lingkungan (Wulandari et al., 2017). Setiap anak juga memiliki kemampuan yang berbeda-beda, baik dari aspek kognitif, afektif maupun psikomotorik. Dalam pemrosesan informasipun anak-anak di kelas ada yang cepat (fast learner), sedang (middle learner) dan lambat (slowlearner). Dari keragaman kemampuan anak tersebut dalam mengaplikasikan pengelolaan kelas yang multikultural mensyaratkan adanya "penghargaan" terhadap keragaman kemampuan anak. Hal ini didasarkan pada pendapat bahwa setiap anak adalah unik dan istimewa. Oleh karenanya, untuk mengembangkan potensi mereka perlu adanya bantuan, bimbingan dan arahan dari guru agar dapat mengembangkan seluruh potensi secara optimal

Melalui pengelolaan kelas yang multikultural diharapkan potensi kemampuan peserta didik dapat dikembangkan secara maksimal. Adapun aspek-aspek keragaman kemampuan peserta didik menurut Gardner (1990) diklasifikasi menjadi delapan macam kecerdasan yang oleh Deporter dkk disingkat menjadi SLIM n BIL (De Porter, Bobby, 2010). Antara lain:

1. Spasial-Visual; kecerdasan yang berkaitan dengan keterampilan berpikir dalam citra dan gambar

2. Linguistik-Verbal; kemahiran dalam berpikir dalam kata-kata atau berbahasa

3. Interpersonal; kecerdasan berkaitan dengan keterampilan berpikir lewat berkomunikasi dengan orang lain, biasanya ditandai dengan kepekaan perasaan intensi, motivasi, watak, temperamen orang lain

4. Musikal-Ritmik; kemampuan berpikir dalam irama dan melodi, identik memiliki kepekaan terhadap ritme, notasi dan melodi.

5. Naturalis; berpikir dalam acuan alam

6. Badan-Kinestetik; kemampuan berpikir melalui sensasi dan gerakan fisik, ditandai dengan kemampuan menggunakan tubuh atau gerak tubuh untuk mengekspresikan gagasan dan perasaan seperti ada pada aktor, atlet, penari, pemahat, dan ahli bedah.

7. Intrapersonal; kemampuan berpikir secara reflektif

8. Logis-Matematis; kemampuan berpikir dengan penalaran atau logika

Adapun strategi pengelolaan kelas yang menghargai keragaman kecerdasan siswa antara lain; Thomas Amstrong (2002) mengajukan beberapa strategi dalam menarik perhatian siswa di kelas sebagaimana pada tabel B.1 berikut.

Tabel B.1 Strategi pengelompok siswa berdasarkan tipe kecerdasan

\begin{tabular}{|c|l|l|l|}
\hline No & Tipe kecerdasan & \multicolumn{1}{|c|}{ Strategi pengelompokan } \\
\hline 1 & $\begin{array}{l}\text { Kecerdasan } \\
\text { linguistic }\end{array}$ & $\begin{array}{l}\text { Mengelompokkan siswa berdasarkan huruf } \\
\text { pertama }\end{array}$ \\
\hline 2 & Logis-Matematis & Mengelompokkan siswa berdasarkan urutan angka \\
\hline
\end{tabular}

Vol. 13 No. 2 Juni 2021

Madrasah homepage: http://ejournal.uin-malang.ac.id/index.php/madrasah/index 


\begin{tabular}{|c|l|l|}
\hline & & $\begin{array}{l}\text { satu sampai dengan jumlah kelompok yang akan } \\
\text { dibuat }\end{array}$ \\
\hline 3 & Kecerdasan spasial & $\begin{array}{l}\text { Mengelompokkan siswa berdasarkan warna } \\
\text { kesukaan }\end{array}$ \\
\hline 4 & Kinestetis-Jasmani, & $\begin{array}{l}\text { Mengelompokkan siswa berdasarkan kecerdasan } \\
\text { gerak, misalnya carilah teman yang bisa melompat } \\
\text { dengan satu kaki, dan sebagainya }\end{array}$ \\
\hline 5 & Kecerdasan Musikal & $\begin{array}{l}\text { Mengelompokkan siswa berdasarkan lagu-lagu } \\
\text { anak-anak yang mereka sukai }\end{array}$ \\
\hline 6 & Kecerdasan natural & $\begin{array}{l}\text { Mengelompokkan siswa berdasarkan hewan } \\
\text { kesukaan dengan cara menirukan suara. }\end{array}$ \\
\hline 7 & $\begin{array}{l}\text { Kecerdasan } \\
\text { Interpersonal }\end{array}$ & $\begin{array}{l}\text { Membuat kelompok-kelompok peserta didik dari } \\
\text { latar belakang berbeda }\end{array}$ \\
\hline 8 & $\begin{array}{l}\text { Kecerdasan } \\
\text { Intrapersonal }\end{array}$ & $\begin{array}{l}\text { Mengelompokkan siswa untuk membuat proyek- } \\
\text { proyek tertentu dengan tema yang berbeda-beda }\end{array}$ \\
\hline
\end{tabular}

Sumber: (Mustafida dan Gafur, 2019)

Berdasarkan macam-macam strategi pengelolan kelas di atas, maka guru sebagai pengelola kelas sedapat mungkin mampu menentukan strategi pengelolaan kelas apa yang tepat dan cocok digunakan. Oleh karenanya, untuk menjamin keberhasilan sebuah manajemen kelas perlu ada dukungan khusus dari guru dan lembaga sekolah untuk bersama-sama melakukan inovasi-inovasi pengelolaan kelas yang berbasis multikultural.

\section{KESIMPULAN}

Guru sebagai pengelola kelas memiliki peran dan tanggung jawab untuk menyelenggarakan dan membina kelas agar tetap kondusif dari waktu ke waktu. Kondisi kelas yang plural dan heterogen menuntut adanya upaya pengorganisasian kelas yang dapat mengakomodir segala keragaman siswa. Oleh karenanya, sebelum bertindak sebagai pengelola kelas, guru perlu membekali diri dengan pemahaman terhadap konsep-konsep pengelolaan kelas yang respek terhadap keragaman. Dengan pemahaman tersebut, modal dasar untuk menciptakan lingkungan atau iklim kelas yang menghargai keragaman (multikultural).

Strategi pengelolaan kelas multikultural perlu diimplementasikan demi menciptakan lingkungan belajar yang kondusif dan ramah akan perbedaan. Melalui pengelolaan kelas yang multikultural inilah keterampilan-keterampilan untuk mengembangkan diri, bekerjasama dengan orang lain yang mendukung terhadap keragaman dan keadilan sosial dapat dikembangkan.

\section{REFERENSI}

Amstrong, Thomas. (2002). Setiap Anak Cerdas: Panduan Membantu Anak Belajar Dengan Memanfaatkan Multiple Intelligence-Nya. Jakarta: PT. Gramedia Pustaka.Agus Surata 
dan Tuhana Taufiq Andrianto. (2001). Atasi konflik Etnis. Global Pustaka Utama. Arends, R. I. (2008). Learning to Teach (seventh edition) (New york: McGraw Hill Companies) (p. 287). Pustaka Pelajar,.

Arikunto, S. (1992). Pengelolaan Kelas dan Siswa (3rd ed.). CV. Rajawali.

Chandra, R. (2015). Classroom management tools for effective teaching. International Journal of Education and Psychology Research.

Dale H, S. (2012). Learning Theories an Educational Perspective. Sixth edition. Pustaka Pelajar.

De Porter, Bobby, trj. A. N. (2010). Quantum Teaching (Orchestrating Student Sucses). Terjemah Quantum Teaching (mempraktekkan quantum learning di ruang-ruang kelas). Kaifa.

Djigic, G., \& Stojiljkovic, S. (2011). Classroom management styles, classroom climate and school achievement. Procedia - Social and Behavioral Sciences. https:// doi.org/10.1016/j.sbspro.2011.11.310

Erwinsyah, A. (2017). Manajemen kelas dalam meningkatkan efektifitas proses belajar mengajar. TADBIR: Jurnal Manajemen Pendidikan Islam.

Gregory, A., \& Jones, J. R. (2013). Secondary classroom management. In Educational psychology handbook series.

Hamka Abdul Aziz. (2012). Pendidikan Karakter Berpusat pada Hati. Al-Mawardi Prima.

Hardy, I., \& Woodcock, S. (2015). Inclusive education policies: Discourses of difference, diversity and deficit. International Journal of Inclusive Education. https://doi.org/10.1080/13603116.2014.908965

Hue, M. T., \& Li, W. S. (2008). Classroom management: Creating a positive learning environment. In Classroom Management: Creating a Positive Learning Environment.

Imron, A. dkk. (2003). Manajemen Pendidikan. Universitas Negeri Malang.

James S. Cangelosi. (2013). Classroom Management Strategies: Gaining and Maintaining Students' Cooperation (SEVENTH ED). Wiley.

Jill Jesson, Lydia Matheson, F. M. L. (2011). Doing Your Literature Review: Traditional and Systematic Techniques. Sage Publications.

Junaidi, M. (2017). Pendidikan Multikultular Dan Pendidikan Inklusi Gender. Jurnal Pendidikan Islam. https:// doi.org/10.38073/jpi.v7i2.48

Kadir, F. (2014). Keterampilan Mengelola Kelas Dan Implementasinya Dalam Proses Pembelajaran. Jurnal Al-Ta'dib.

Kang, H. S. (Theresa), Kim, E. J., \& Park, S. (2019). Multicultural teaching efficacy and cultural intelligence of teachers: The effects of learning goal orientation and training readiness. International Journal of Educational Management. https://doi.org/10.1108/IJEM-11-2017-0318

Lawrence A. Machi, B. T. M. (2016). The Literature Review: Six Steps to Success. corwin. M. Syaom Barliana. (2008). Pengembangan Program Pendidikan IPS Berbasis Multikultural,Konvensi Nasional Pendidikan Indonesia VI (Konaspi),.

Mustafida, Fita, Abd, G. (2019). Strategi Pengelolaan Kelas (teori dan praktek menciptakan lingkungan kelas multikultural). UIN-Malang Press.

Mustafida, F. (2016). Strategi Menciptakan Iklim Kondusif di SD/MI (Sebuah Kajian Pedagogis Dan Psikologis). Madrasah. https:// doi.org/10.18860/jt.v8i2.3775

Nadda, P. (2017). Teaching Strategies in a Multicultural Classroom. Imperial Journal of Interdisciplinary Research (IJIR).

Vol. 13 No. 2 Juni 2021

Madrasah homepage: http://ejournal.uin-malang.ac.id/index.php/madrasah/index 


\section{MADRASAH}

Jurnal Pendidikan dan Pembelajaran Dasar

p ISSN: 1979-5599 | e ISSN: 2502-194X

Nawawi, H. (1982). Organisasi Sekolah dan Pengelolaan Kelas sebagai Lembaga Pendidikan. Gunung Agung.

Nugraha, M. (2018). MANAJEMEN KELAS DALAM MENINGKATKAN PROSES PEMBELAJARAN. Tarbawi: Jurnal Keilmuan Manajemen Pendidikan. https:// doi.org/10.32678/tarbawi.v4i01.1769

Oliver, R. M., Wehby, J. H., \& Reschly, D. J. (2011). Teacher classroom management practices: effects on disruptive or aggressive student behavior. Campbell Systematic Reviews. https://doi.org/10.4073/csr.2011.4

Parker, C. (2016). Peace Building Citizenchip, and Identity (Empowering Conflict and Dialogue in Multicultural Classroom). Sense Publisher.

Ritzer, G. (1991). Sosiology: Experiencing a Changing Society,. Allyn and Bacon.

Shepherd, T. L., \& Linn, D. (2017). Behavior and Classroom Management in the Multicultural Classroom: Proactive, Active, and Reactive Strategies. In Behavior and Classroom Management in the Multicultural Classroom: Proactive, Active, and Reactive Strategies. https:/ / doi.org/10.4135/9781483366647

Sleeter, C. E. (2001). Preparing teachers for culturally diverse schools: Research and the overwhelming presence of whiteness. Journal of Teacher Education. https://doi.org/10.1177/0022487101052002002

Smith, C. J. (2012). Ethical Behaviour in the E-Classroom. In Ethical Behaviour in the EClassroom. https:/ / doi.org/10.1533/9781780633060

Sturz, D. L., Kleiner, B. H., \& Fernandez, A. (2005). Effective management of cultural diversity in a classroom setting. Equal Opportunities International. https://doi.org/10.1108/02610150510788169

Suteja, J. (2017). DAMPAK POLA ASUH ORANG TUA TERHADAP PERKEMBANGAN SOSIAL-EMOSIONAL ANAK. AWLADY : Jurnal Pendidikan Anak. https://doi.org/10.24235/awlady.v3i1.1331

Syarifah, H. (2017). PENDIDIKAN DALAM KELUARGA. Raudhah Proud To Be Professionals : Jurnal Tarbiyah Islamiyah. https:/ / doi.org/10.48094/raudhah.v2i1.18

Thomas Amstrong, . (2002). Setiap Anak Cerdas: Panduan membantu anak belajar dengan memanfaatkan multiple intelligence-nya. PT. Gramedia Pustaka.

Tilaar, H. (2003). Kekuasaan dan Pendidikan. Indonesia Tera.

Tomlinson, C. A., \& Imbeau, M. B. (2010). A Differentiated Classroom. In Leading and Managing a Differentiated Classroom.

van Tartwijk, J., den Brok, P., Veldman, I., \& Wubbels, T. (2009). Teachers' practical knowledge about classroom management in multicultural classrooms. Teaching and Teacher Education. https:/ / doi.org/10.1016/j.tate.2008.09.005

Wiseman, D. G., \& Hunt, G. H. (2008). Best practice in motivation and management in the classroom. Second Edition. Charles C. Thomas, Publisher, Ltd.

Wulandari, R., Ichsan, B., \& Romadhon, Y. A. (2017). PERBEDAAN PERKEMBANGAN SOSIAL ANAK USIA 3-6 TAHUN DENGAN PENDIDIKAN USIA DINI DAN TANPA PENDIDIKAN USIA DINI DI KECAMATAN PETERONGAN JOMBANG. Biomedika. https:// doi.org/10.23917/biomedika.v8i1.2900

Yaqin, M. A. (2005). Pendidikan Multikultural: Cross-Cultural Understanding untuk Demokrasi dan Keadilan. Pilar Media.

Zamroni. (2011). Pendidikan Demokrasi pada Masyarakat Multikultural,. Gavin Kalam

Vol. 13 No. 2 Juni 2021

Madrasah homepage: http://ejournal.uin-malang.ac.id/index.php/madrasah/index 
Utama.

Vol. 13 No. 2 Juni 2021

Madrasah homepage: http://ejournal.uin-malang.ac.id/index.php/madrasah/index 